\title{
PERILAKU AGRESIF ANGGOTA ORGANISASI EMASYARAKATAN (ORMAS) “X” DI PROVINSI D.I. YOGYAKARTA
}

\author{
Ibnu Sutowo\&Susilo Wibisono \\ Program Studi Psikologi Universitas Islam Indonesia \\ Jalan Kaliurang Km 14,5 Besi Sleman DIY 55584 \\ wibisonosusilo@yahoo.com
}

\begin{abstract}
This research is aimed to understand psychological dynamics of aggressive behaviors among the social organization's membersin Jogjakarta. This research usedqualitative approach. Respondents were the active members of the social organization (ormas) " $X$ " in Jogjakarta. The result shows some factors that influence the aggressive behavior among the members, which are group influence, deindividuation, frustration, drug or alcoholic and physical environmental. The aggressive behaviors were done by the members of ormas " $X$ " are included physical and verbal aggression. Physical aggressionswere done by member of ormas " $X$ ” such as destruction of public facilities, injuring another person and inter-group conflict. Verbal aggressionswere done by member of ormas "X"such as harassment, oppression and intimidation to the victims. The aggressive behaviors among the member of ormas $\mathrm{X}$ were done spontaneously. On the other hand, aggression done by ormas " $\mathrm{X}$ " to other organization or group also includes an invisibility aggression such as refusing to support other organization, rejection from agreement, and boycott the other's activities.
\end{abstract}

Keywords: aggressive behavior, social organization (ormas).

\begin{abstract}
Abstrak
Penelitian ini dilakukan untuk memahami dinamika psikologis perilaku agresif anggota organisasi kemasyarakatan (ormas) di Provinsi D.I Yogyakarta. Metode penelitian ini adalah metode kualitatif. Responden adalah anggota aktif ormas yang pernah terlibat dalam peristiwa kekerasan yang dilakukan oleh kelompok ormas tersebut. Hasil analisis data menemukan beberapa faktor yang mempengaruhi perilaku agresi anggota
\end{abstract}


ormas "X" ini meliputi pengaruh kelompok, deindividuasi, frustrasi, alkohol dan obat-obatan, serta lingkungan fisik tempat tinggal. Perilaku agresif yang dimunculkan oleh anggota ormas meliputi agresi fisik dan agresi verbal.Agresi fisik berupa perusakan sarana umum, melukai korban, dan pertikaian antar kelompok.Agresi verbal berupa pelecehan, penindasan, intimidasi. Perilaku agresif anggota ormas " $X$ " dilakukan secara spontan, seperti melakukan serangan balasan ketika salah satu anggotanya menjadi korban pengeroyokan, melakukan penindakan pada isu-isu tertentu yang terjadi dengan segera, dan melakukan penyerangan ketika ada kelompok lain yang mengancam keberadaan ormas " $X$ ”. Perilaku agresif yang anggota ormas " $X$ ” terhadap kelompok atau instansi lain juga meliputi perilaku agresif yang tidak tampak secara langsung. Hal ini antara lain berupa perilaku tidak memberikan dukungan, menolak diajak kerja sama, dan melakukan boikot terhadap kegiatan tertentu.

Kata Kunci: organisasi kemasyarakatan (ormas), perilaku agresif

\section{Pendahuluan}

Tindak kekerasan dan perilaku agresif terjadi hampir di berbagai penjuru dunia dan seluruh level masyarakat. Tindak kekerasan yang terjadi di Indonesia dapat dikatakan telah berada pada level yang sangat mengkhawatirkan. Hal ini antara lain dapat dilihat dari semakin maraknya aksi perampokan bersenjata, tawuran pelajar, tawuran antar pemuda, tawuran suporter sepak bola, tawuran mahasiswa, penindasan terhadap suatu kelompok atau organisasi tertentu, dan masih banyak lagi. Salah satu faktor yang paling dominan terkait dengan kekerasan adalah perilaku agresif, baik dalam konteks individu maupun kelompok.

Perilaku agresif adalah tindakan menyerang yang disertai dengan kekerasan baik secara fisik maupun non-fisik terhadap lingkungan, orang lain maupun diri sendiri. Secara fisiologis, hal ini terkait dengan mekanisme otak, bahkan mengalami peningkatan pasca terjadinya kejadian yang traumatis pada otak (Karli, 2006; Saout, dkk, 2011). Agresi fisik menurut Schultz \& Videbeck(Videbeck, 2008) ialah perilaku menyerang atau melukai orang lain yang juga mencakup perusakan properti, penghinaan, ancaman, intimidasi dan caci maki. Perilaku agresif mengandung beberapa motif, antara lain untuk menyakiti orang lain, menghukum orang lain, atau memaksa orang lain untuk patuh. Bentuk lain perilaku agresif adalah agresif verbal, yaitu emosi yang diungkapkan melalui kata-kata yang melecehkan, tidak adanya kerja sama, 
pelanggaran aturan atau norma, atau perilaku mengancam (Stuart \& Sundeen, 1991; Vanbrabant, 2012; Bergsmann, De Schoot, Schober, Finsterwald, Spiel, 2013).

Salah satu kasus kekerasan yang banyak terjadi di Indonesia adalah tindak kekerasan oleh sekelompok orang yang tergabung dalam organisasi kemasyarakatan (ormas). Ormas yang berhaluan radikal sering kali melakukan tindakan negatif yang merugikan masyarakat seperti penindasan, pencekalan, sweeping, intimidasi, bahkan tawuran antar anggota ormas. Data kekerasan yang dilakukan oleh anggota Ormas cenderung menunjukkan peningkatan frekuensi dari tahun ke tahun. Hal ini tercermin dari data yang dirilis oleh Kepolisian Republik Indonesia (POLRI), bahwa antara tahun 2007-2010 telah terjadi sebanyak 107 kasus kekerasan yang dilakukan oleh anggota ormas. Pada tahun 2007 terjadi 10 kasus, tahun 2008 terjadi 8 kasus, kemudian tahun 2009 terjadi 40 kasus dan hingga Agustus 2010 telah meningkat menjadi 49 kasus (Kompas, 30 Agustus 2010). Data dari Setara Institusi bahkan menyebutkan selama tahun 2010 terjadi 117 kasus kekerasan ormas, dan meningkat menjadi 244 kasus pada tahun 2011 (Salam, 2012).

Organisasi kemasyarakatan (Ormas) adalah perkumpulan sosial yang dibentuk oleh masyarakat, baik yang berbadan hukum maupun tidak berbadan hukum. Fungsi ormas pada dasarnya adalah sebagai sarana partisipasi masyarakat dalam pembangunan bangsa dan negara. Wiese dan Becker (George \& Jones, 2002) mengemukakan bahwa ormas merupakan suatu jaringan dari proses-proses hubungan antar manusia dan antar kelompok yang berfungsi memelihara hubungan tersebut serta pola-polanya, sesuai dengan kepentingan manusia dan kelompoknya.

Maraknya ormas pasca reformasi 1998 pada umumnya dilatarbelakangi oleh keinginan masyarakat untuk berpartisipasi, berkumpul, berpendapat, menyatakan pikiran, dan berkomunikasi antar anggota ormas. Dampak positif yang dibawa adalah terbantunya masyarakat melalui acara-acara sosial seperti pengobatan gratis, khitanan massal, wadah penyaluran bantuan dan masih banyak lagi pern positif yang lain. Namun demikian, muncul juga ekses negatif berupa kecenderungan ormas tertentu yang bersikap arogan, agresif, anarkis, intimidatif, merusak dan bentuk pelanggaran hukum lainnya. Perilaku agresif yang dilakukan anggota ormas saat ini merupakan salah satu problem sosial yang mendesak untuk diselesaikan.

Salah satu faktor perilaku agresif adalah pengaruh kelompok (Sarwono, 1999). Secara konseptual, Vasquez, Lickel, dan Hennigan (2010) menyebutnya sebagai perilaku agresif berbasis kelompok. Pengaruh kelompok dalam perilaku agresif berupa menurunnya kendali moral yang kemudian mendorong munculnya perilaku agresif. Individu cenderung memunculkan perilaku agresif ketika memperoleh provokasi 
secara langsung dari kelompoknya. Selain itu, adanya desakan dari kelompok dan identitas kelompok (seperti persepsi kalau tidak ikut terlibat dalam aktivitas kelompok akan dianggap bukan anggota kelompok) dapat menyebabkan individu melakukan perilaku agresif (Charters, Duffy \& Nesdale, 2013; Farmer \& Xie, 2007).

Di Provinsi Daerah Istimewa Yogyakarta (DIY), fenomena ormas baru juga berkembang secara pesat. Hal ini diindikasikan oleh berdirinya beberapa ormas yang bermarkas di wilayah DIY, seperti Front Pembela Islam (FPI), Contrast, Gerakan Pemuda Ka’bah (GPK), Gerakan Pemuda Anshar (GPA), Persatuan Pemuda Muslim Yogyakarta (PPMY), Forum Jogja Rembug (FJR), dan lain sebagainya. Selain itu, adanya Dana Keistimewaan sebagai implikasi UU Keistimewaan Yogyakarta juga sangat mungkin memicu lahirnya berbagai ormas baru dalam bidang-bidang yang masuk alokasi dana keistimewaan tersebut.

Setiap ormas didirikan dengan mengusung visi misi yang mulia. Namun demikian, penyimpangan dari nilai-nilai mulia dalam visi misi yang diusung juga marak terjadi di kalangan berbagai ormas. Hal ini antara lain berupa munculnya perilaku-perilaku kekerasan anggota ormas tersebut. Parahnya, perilaku kekerasan yang terjadi seringkali didasari oleh kepentingan tertentu seperti perebutan lahan parkir, pembebasan lahan, debt collector, pengawalan terhadap tokoh/individu tertentu, sweeping, dan penyerangan terhadap individu atau kelompok lain dengan tujuan-tujuan tertentu.

Berdirinya berbagai ormas di suatu wilayah dapat dipahami sebagai proses deprivasi relatif, yakni ketidakpuasan individu-individu tertentu yang diakibatkan bukan oleh kondisi obyektif, tetapi oleh perasaan subyektif, seperti merasa "kalah" atau tidak beruntung dibandingkan individu-individu lain (Gurr \& Runciman dalam Niens \& Cairns, 2007). Dapat pula dikatakan bahwa berdirinya ormas dilandasi oleh dorongan untuk mencapai rasa aman, status, peningkatan harga diri kolektif, kekuasaan, dan tujuan lain yang hanya dapat dicapai individu hanya jika ia berserikat. Hal ini memicu terjadinya kesenjangan dan kategorisasi sosial yang mendorong individu-individu tersebut membentuk kelompok untuk mengekspresikan perasaan tertindas dan terpinggirkan. Individu-individu tersebut selanjutnya saling mengidentifikasikan perasaan masing-masing dan menemukan kesamaan tujuan yang mendasari terbentuknya suatu perkumpulan guna menuntut keadilan atau merubah suatu nilai dan struktur yang berlaku. Keberadaan organisasi kemasyarakatan seharusnya memberikan dampak yang positif bagi masyarakat maupun anggota, namun akhir-akhir ini muncul gejala yang mengkhawatirkan berupa tindakan-tindakan kekerasan yang dilakukan oleh ormas-ormas tertentu dengan merugikan dan mendiskriminasikan kelompok lain. 
Perkembangan teori yang dikenal sebagai teori identitas sosial mengatasi banyaknya masalah teoritis yang melekat dalam teori perilaku agresif (Tajfel \& Turner dalam Niens \& Cairns, 2007). Teori identitas sosial memiliki beberapa keunggulan dibandingkan teori-teori agresi yang lain dalam hal :(1) Secara tegas dikategorikan di dalam teori sosial; (2) tidak membuat asumsi tentang abnormalitas; (3) Menyisakan ruang untuk peran disiplin ilmu yang lain; dan (4) Menyajikan informasi secara lengkap mengenai penyelesaian serta penyebab konflik sosial. Selain menggunakan teori identitas sosial, perilaku agresif dalam konteks kelompok juga dapat dijelaskan dengan menggunakan teori kepribadian otoriter dan deprivasi relatif.

Dalam teori kepribadian otoriter, Adorno, Brunswik, Levinson dan Sanford (Niens \& Cairns, 2007) menjelaskan bahwa struktur kepribadian individu memberikan dasar bagi berkembangnya sikap tidak toleran. Secara khusus, sebuah pendidikan otoriter adalah ketika disiplin orang tua bergantung pada kekerasan, terbatasnya kebebasan, dan hukuman terhadap ketidaktaatan. Adorno, dkk (Niens \& Cairns, 2007) percaya bahwa permusuhan ditransfer kepada individu atau kelompok yang tampak lebih lemah, perbedaan norma-norma sosial, atau kepada kelompok yang lebih rendah dalam status (misalnya, etnis minoritas) sehingga menjadi peluang timbulnya konflik antar kelompok.

Deprivasi relatif adalah keadaan psikologis ketika individu merasakan ketidakpuasan, kesenjangan, atau kekurangan subjektif yang dirasakan pada saat keadaan diri atau kelompoknya dibandingkan dengan orang atau kelompok lain. Brown (Niens \& Cairns, 2007) mengungkapkan bahwa perubahan ke arah yang berbeda pada dua kelompok yang sebelumnya sama dapat menimbulkan persepsi adanya ketidakadilan, sedangkan perasaan ketidakadilan yang muncul karena deprivasi mendorong lahirnya prasangka. Deprivasi relatif pada umumnya muncul karena ketidakpuasan suatu kelompok terhadap kelompok lain atas pencapaian kelompok tersebut. Hal ini jelas menunjukkan kesenjangan dan berpotensi besar menimbulkan konflik antar kelompok.

Teori identitas sosial menyatakan bahwa konflik antar kelompok disebabkan karena identitas kelompok (Goldberg, 2003; Leonardelli, Pickett \& Brewer, 2010). Dalam realita kehidupan, individu sering dikelompokkan atau dikategorikan atas dasar agama, etnis, atau organisasi yang diikuti. Individu akan selektif menentukan kategori yang dapat memenuhi identitas sosialnya, terutama identitas yang positif, sehingga muncul konsep ingroup-outgroup yaitu menganggap kelompoknya merupakan yang paling benar sementara kelompok lain dianggap salah (ingroup favouritism bias). Tajfel dan Turner (dalam Niens \& Cairns, 2007) menyatakan bahwa manusia memiliki 
kecenderungan untuk membuat kategorisasi sosial atau mengklasifikasikan individu dalam kategori atau kelompok sosial tertentu.

Pada umumnya, individu membagi dunia sosial ke dalam dua kategori yang berbeda, yakni "kita”dan "mereka”."Kita” adalah ingroup sedangkan "mereka” adalah outgroup. Ketika terjadi persaingan antar dua kelompok, maka kelompok lain atau outgroup dipersepsikan sebagai musuh atau ancaman. MacLaren, Best dan Bigney (2010) menyatakan bahwa perilaku agresi dapat muncul sebagai respon atas hadirnya ancaman bagi berbagai aspek penting individu, baik diri, orang terdekat maupun properti yang dimilik. Menurut pandangan ini, perilaku agresif seringkali lahir untuk merespon ancaman (menurut persepsi atau yang sungguh-sungguh ada) yang berasal dari individu atau kelompok lain diluar kelompoknya. Ancaman dapat dipersepsikan sebagai sesuatu yang akan mengenai keselamatan fisik, wilayah kekuasaan atau identitas psikologis anggota kelompok.

Studi ini merupakan satu upaya untuk memahami bagaimana dinamika munculnya perilaku agresif pada anggota ormas " $X$ ” yang ada di Provinsi DIY. Sumbangan yang diharapkan lahir bersama studi ini adalah upaya untuk mengurangi tingkat kekerasan pada level kelompok yang cenderung meningkat di DIY akhirakhir ini. Kerangka teoritik yang dikembangkan dalam penelitian ini mengacu pada apa yang telah diulas di atas bahwa determinan perilaku agresif yang dimunculkan individu dapat dapat dari luar dirinya maupun dari dalam dirinya. Determinan yang datang dari luar diri individu antara lain berupa pengaruh lingkungan dan pengaruh kelompok, sedangkan yang berasal dari dalam diri meliputi faktor kepribadian dan kondisi fisik individu. Penelitian mengenai perilaku agresif dalam setting kelompok telah banyak dilakukan sebelumnya. Kemmelmeier, Broadus dan Padilla (2008) menegaskan bahwa identitas kolektif mengarahkan pada kecenderungan konflik antar kelompok. Penelitian yang dilakukan Demayo, Macabanding, dan Torres (2011) menunjukkan bahwa dalam kebudayaan tertentu, perilaku agresif berlangsung secara turun temurun. Helm, Stams, Genabeek dan der Laan (2012) secara kuantitatif menemukan bahwa iklim kelompok dan faktor kepribadian merupakan determinan perilaku agresi berbasis kelompok. Berbeda dengan beberapa penelitian di atas, penelitian ini merupakan upaya untuk mengeksplorasi secara kualitatif berbagai faktor yang memicu perilaku agresi berbasis kelompok dalam sebuah lembaga formal semacam ormas. Karakteristik khusus yang dimiliki ormas adalah bahwa lembaga ini pada dasarnya memiliki identitas yang positif, namun dalam prakteknya sangat terbuka bagi lahirnya berbagai penyimpangan. 


\section{Metode Penelitian}

Penelitian ini menggunakan metode kualitatif dengan pendekatan studi kasus. Pendekatan ini mengandung konsekuensi bagi peneliti untuk memandang objek yang dikaji secara khusus, sehingga mampu menggali substansi secara rinci dan menyeluruh. Penelitian ini juga menuntut pentingnya kedekatan dengan orang-orang dan situasi penelitian, agar peneliti memperoleh pemahaman jelas tentang realitas dan kondisi kehidupan nyata (Poerwandari, 1998). Kriteria utama dari responden penelitian yang dipergunakan dalam penelitian ini menurut penasehat umum ormas " $X$ ” sebagai informan adalah empat anggota aktif ormas " $\mathrm{X}$ " yang sering terlibat dalam tindak perilaku agresif dan memiliki peranan penting didalam ormas tersebut. Penelusuran data dilakukan dengan menggunakan metode wawancara dan observasi. Bentuk wawancara yang digunakan dalam penelusuran data adalah wawancara terstruktur karena sebelum melakukan wawancara, peneliti sudah membuat pedoman wawancara yang berisi materi-materi wawancara. Beberapa hal yang diobservasi dalam penelitian ini antara lain kondisi lingkungan dan tempat tinggal responden, penampilan fisik, sikap tubuh ketika wawancara, bentuk-bentuk perilaku agresif fisik dan verbal, dan intensitas perilaku agresif tersebut. Secara lebih detail, identitas responden penelitian beserta teknis wawancara disampaikan dalam Tabel 1 di bawah ini:

Tabel 1. Identitas Responden Penelitian

\begin{tabular}{|c|c|c|c|c|c|}
\hline \multirow{2}{*}{ Identitas } & \multicolumn{5}{|c|}{ Responden } \\
\hline & DS & JS & $\mathbf{A M}$ & BA & SW \\
\hline Jenis Kelamin & Laki-laki & Laki-laki & Laki-laki & Laki-laki & $\begin{array}{l}\text { Laki- } \\
\text { laki }\end{array}$ \\
\hline Status & Menikah & Menikah & Lajang & Menikah & Lajang \\
\hline Domisili & Yogyakarta & Sleman & Sleman & Bantul & Bantul \\
\hline Usia & 35 tahun & 35 tahun & 27 tahun & 29 tahun & 42 tahun \\
\hline $\begin{array}{l}\text { Lama bergabung } \\
\text { dengan Ormas } \\
\text { "X" }\end{array}$ & 6 tahun & 5 tahun & 2 tahun & 4 tahun & 3 tahun \\
\hline $\begin{array}{l}\text { Waktu } \\
\text { Wawancara }\end{array}$ & $\begin{array}{l}30 \text { Mei dan } \\
2 \text { Juni } 2012\end{array}$ & $\begin{array}{l}2 \text { Juni dan } \\
4 \text { Juni } \\
2012\end{array}$ & 3 Juni 2012 & $\begin{array}{l}6 \text { Juni } \\
\text { dan } 7 \\
\text { Juni } \\
2012\end{array}$ & $\begin{array}{l}7 \text { Juni } \\
2012\end{array}$ \\
\hline $\begin{array}{l}\text { Lokasi } \\
\text { Wawancara }\end{array}$ & $\begin{array}{l}\text { Base Camp } \\
\text { \& Rumah } \\
\text { Responden }\end{array}$ & $\begin{array}{l}\text { Lokasi } \\
\text { Tanah } \\
\text { Sengketa } \\
\text { dan } \\
\text { rumah } \\
\text { responden }\end{array}$ & $\begin{array}{l}\text { rumah } \\
\text { responden } \\
\text { dan beteng } \\
\text { vrederburg }\end{array}$ & $\begin{array}{l}\text { rumah } \\
\text { responde } \\
\text { n dan } \\
\text { lokasi } \\
\text { tanah } \\
\text { sengketa }\end{array}$ & $\begin{array}{l}\text { lokasi } \\
\text { tanah } \\
\text { sengketa }\end{array}$ \\
\hline
\end{tabular}


Berdasarkan hasil wawancara dan observasi kepada subyek penelitian kemudian dilakukan analisis data. Pemberdayaan potensi anggota di ormas “ $X$ ” pun terbagi didalam berbagai bidang seperti pertanian, perikanan, peternakan, kesenian, mediasi konflik, keamanan, dan advokasi. Kegiatan ormas “X” pada umumnya lebih bersifat sosial seperti melakukan pendistribusian bantuan untuk membantu korban bencana alam, penghijauan kawasan wisata sebagai wujud pelestarian alam, pelestarian kesenian lokal, dan melakukan bakti sosial. Berdasarkan penelusuran data yang dilakukan melalui wawancara dan observasi, latar belakang keputusan responden menjadi anggota ormas meliputi beberapa motif, yaitu:

\section{a. Motif sosial}

Latar belakang responden bergabung karena ormas “ $X$ ” dapat menjadi wadah sosial bagi anggota-anggotanya seperti, menambah teman, menambah saudara, dan berkumpul dalam satu wadah dengan visi dan misi yang sama. Responden juga mengungkapkan bahwa latar belakang bergabung dengan ormas "X” karena ingin mengabdi bagi daerah dengan cara menjaga suasana kondusif dan keamanan di wilayah Yogyakarta dan sekitarnya dan membantu meringankan beban masyarakat dengan menjadi relawan korban bencana alam.

\section{b. Memperoleh rasa aman}

Motif memperoleh rasa aman juga dapat menjadi dasar bagi keputusan untuk bergabung dalam ormas. Rasa aman ini meliputi rasa aman secara ekonomi dan dalam menjalankan aktivitas pekerjaan. Responden merasa bahwa dengan menjadi anggota ormas, maka ia lebih memiliki keberanian dalam menjalankan dan menghadapi persaingan usaha.

Perilaku agresif yang dimunculkan oleh anggota ormas meliputi agresi fisik dan agresi verbal. Agresi fisik meliputi perusakan sarana umum, melukai korban, dan pertikaian antar kelompok hingga menimbulkan korban. Secara verbal, perilaku agresif anggota ormas juga muncul dalam bentuk pelecehan, penghinaan, dan intimidasi. Hal ini membawa implikasi yang signifikan bagi korban agresi verbal tersebut. Walaupun secara fisik korban baik-baik saja namun korban mengalami trauma secara psikis. Hal ini antara lain dapat dilihat pada beberapa kutipan wawancara di bawah ini:

"Ya namanya orang emosi, saya banting beberapa gelas dan botol miras, melempar kursi di panggung, saya tendang pengunjung yang sedang mabuk disebelah saya”. (W2, 86-89) 
“Eeem, ya saya ancam security nya kalo gak bisa nemuin pengeroyok Monyong diskotek ini akan kami sweeping”. (W2, 80-83)

Perilaku agresif anggota ormas “ $X$ ” dilakukan secara spontan, seperti melakukan serangan balasan ketika salah satu anggotanya menjadi korban pengeroyokan, melakukan penindakan pada isu-isu tertentu yang terjadi dengan segera, dan melakukan penyerangan ketika ada kelompok lain yang mengancam keberadaan ormas “ $X$ ”. Berdasarkan informasi responden, perilaku agresif yang dimunculkan anggota ormas “ $X$ ” terhadap kelompok atau instansi lain juga meliputi perilaku agresif yang tidak tampak secara langsung. Hal ini antara lain berupa perilaku tidak memberikan dukungan, menolak diajak kerja sama dengan pihak yang berwajib, dan melakukan boikot terhadap kegiatan tertentu. Pada aspek hasutan, perilaku agresif dapat muncul sebagai akibat provokasi dari kelompok maupun bentuk balasan terhadap serangan kelompok lain. Hal ini antara lain tercermin dari kutipan hasil wawancara berikut ini:

"Deni itu kan mbelot ikut Ormas "Y" sekarang, nah itu yang bikin tementemen gak terima, saya yang dulunya bawa dia masuk " $X$ ” kan malu sama si boss, ya udah saya kasih pelajaran aja itu anak”. (W5, 168-172)

"Ya seperti saat melakukan penyerangan di diskotek kemaren, Eeemm jadi salah satu anggota saya dikeroyok disana kemudian saya dapet kabar terus saya kumpulkan beberapa anak buah kemudian kita menggeruduk kesana”. (W2, 73-78).

Tindak kekerasan dan perilaku agresif yang dilakukan oleh anggota ormas “X” mengakibatkan kerugian baik pada pelaku maupun korban dan lingkungan sekitar. Hal ini sebagaimana yang dijelaskan responden bahwa dampak perilaku agresif bagi korban menghasilkan luka fisik dan secara psikologis memunculkan ketakutan, trauma, dan kemarahan. Sedangkan bagi anggota ormas “ $X$ ” sendiri sebagai pelaku , dampak yang ditimbulkan meliputi sanksi dari ketua ormas, ditangkap pihak yang berwajib, bertambahnya jumlah musuh. Dampak bagi lingkungan sekitar adalah, mengganggu ketertiban, rusaknya sarana umum, dan berkurangnya simpati masyarakat. Pada aspek unit sosial yang terlibat, Tindak kekerasan dan perilaku agresif yang dilakukan anggota ormas “ $X$ ” dilakukan secara berkelompok, responden mengungkapkan bahwa perilaku yang mengarah pada tindakan-tindakan kekerasan dilakukan secara beramairamai atau berkelompok. Hal ini antara lain terlihat dari kutipan hasil wawancara berikut ini:

"Kemudian saya keluar sama teman-teman saya, kemudian saya dicegat di jalan masuk TPR sama banyak orang, mau gak mau saya harus nekat 
kemudian saya ribut disana bersama teman-teman saya dan gak bakalan lagi maen kesana lah kemudian saya habisi semua itu yang di TPR itu”. (W3, 16-23)

"Lha kemaren jaga di lokasi sengketa kemaren kita ribut sama pihak yayasan yang bawa preman kita lawan masuk ke lokasi sengketa sambil mecahin kaca”. (W4, 151-154)

"Ya mengawasi kalo ada orang asing yang masuk ke daerah sengketa kita usir... Itu ya kita masang papan seng, kita tutupi semua pagar lokasi sengketa dengan seng”. (W5, 42-26)

Berdasarkan hasil analisis data, beberapa faktor yang mempengaruhi perilaku agresif anggota ormas " $X$ ” meliputi pengaruh kelompok, factor hilangnya kesadaran sebagai individu, frustrasi, pengaruh alkohol dan obat-obatan, serta lingkungan fisik tempat tinggal. Pengaruh kelompok dalam perilaku agresif menyebabkan individu dalam kelompok akan memiliki kepercayaan diri yang sangat tinggi. Individu menganggap kelompok mereka sangat unggul dan tidak pernah kalah dalam segala hal, dengan keputusan yang diambil dan kemampuan yang mereka miliki oleh sebab itu kelompok akan menghilangkan kontrol sosial yang dimiliki dengan meresponnya dalam bentuk agresi. Responden mengungkapkan bahwa perilaku agresif muncul, salah satunya karena status dalam kelompoknya sebagai koordinator sehingga responden melakukan tindak kekerasan karena dipengaruhi oleh keputusan kelompok.

Deindividuasi memiliki efek memperbesar keleluasaan individu dalam melakukan agresi, karena menyingkirkan atau mengurangi peranan beberapa aspek yang terdapat pada individu, yakni identitas diri atau personalitas. Responden melakukan perilaku agresif secara berkelompok karena dapat dengan mudah menghilangkan jejak keterlibatan personal. Perilaku agresif yang dilakukan anggota ormas “ $X$ ” juga dipengaruhi faktor frustrasi, yakni ketika kelompok gagal atau terhambat dalam mencapai sesuatu yang diinginkan. Pengaruh alkohol juga menjadi salah satu faktor perilaku agresif pada anggota ormas " $X$ ”. Seseorang yang mengkonsumsi alkohol akan sebih sulit mengendalikan emosinya dan cenderung melakukan perbuatan destruktif. Responden mengungkapkan jika sedang dalam keadaan mengkonsumsi alkohol, dirinya cenderung agresif dan emosional.

Berdasarkan observasi yang dilakukan peneliti, semua responden berasal dari situasi lingkungan fisik perkotaan yang padat penduduknya. Rumah dan lingkungan permukiman akan memberi pengaruh psikologis bagi penghuninya. Kepadatan yang tinggi merupakan stressor lingkungan yang dapat memicu stress, penyakit, atau akibatakibat negatif pada perilaku masyarakat, sehingga lingkungan fisik dan tempat tinggal sangat mempengaruhi perilaku-perilaku yang dimunculkan oleh anggota ormas " $\mathrm{X}$ ”. 


\section{Pembahasan}

Penelitian ini menemukan beberapa indikasi perilaku agresif anggota ormas "X”, baik secara fisik maupun verbal. Bentuk perilaku agresif yang ditunjukkan anggota ormas “ $X$ ” beragam, seperti mengintimidasi, melukai, memukul, maupun merusak benda-benda. Hal ini dilakukan secara individual maupun berkelompok. Kecenderungan perilaku agresif dalam lingkup ormas atau kelompok ini relevan dengan apa yang diungkapkan Baron \& Bryne (2000) bahwa Faktor yang menyebabkan perilaku agresif anggota ormas kebanyakan disebabkan oleh pengaruh kelompok.

Berdasarkan analisis yang dilakukan peneliti, faktor-faktor lain yang menyebabkan perilaku agresif pada responden adalah deindividuasi, kepatuhan dan kekuasaan, provokasi, dan pengaruh alkohol. Hal ini sesuai dengan pendapat Berkowitz (Koeswara, 1998) bahwa faktor-faktor yang mempengaruhi perilaku agresi yaitu frustasi, stres, deindividuasi, kepatuhan dan kekuasaan, provokasi, serta pengaruh alkohol dan obatobatan. Penelitian ini juga mendukung asumsi bahwa perilaku agresif yang dimunculkan individu terkait dengan setting lokasi tempat tinggal. Individu yang tinggal dalam setting lingkungan tempat tinggal yang padat cenderung lebih agresif dibandingkan individu yang tinggal dalam setting lingkungan yang longgar. Adanya perilaku agresif yang dimunculkan oleh beberapa anggota ormas “ $X$ ” akan menimbulkan reaksi negatif. Hal ini sangat bergantung bagaimana individu mempersepsikannya. Bentuk perilaku-perilaku dalam berkelompok dan beorganisasi yang positif akan menghasilkan berbagai usaha untuk mengurangi perilaku agresif. Usaha yang dilakukan biasanya adalah dengan berusaha menghindari konflik dengan kelompok lain, mengutamakan musyawarah, mengurangi konsumsi alkohol, memperbanyak kegiatan-kegiatan sosial dan spiritual, dan menegakkan aturan organisasi.

Anderson, Deuser, dan DeNeve (Myers, 1999) menyatakan bahwa munculnya perilaku agresif didasari oleh adanya ketidaknyamanan, frustrasi, merasa diserang dan berada dalam situasi yang kacau. Kondisi-kondisi ini kemudian memicu munculnya pikiran bermusuhan, perasaan marah dan gairah untuk melepaskan kemarahan. Hal inilah yang kemudian mendorong munculnya perilaku agresif individu. Kondisi ini terjadi baik dalam konteks individu maupun kelompok.Frustrasi dalam konteks inidividu, selain memberikan peluang bagi munculnya perilaku agresif keluar (outward agression) terhadap pihak lain, juga memberikan peluang munculnya perilaku agresif ke dalam (inward agression) yang muncul dalam bentuk bunuh diri. Namun dalam konteks kelompok, ketika individu merasakan kondisi deindividuasi dan kepercayaan diri yang berlebih, kecenderungan perilaku agresif keluar akan semakin kuat (Myers, 1999). 
Berdasarkan hasil analisis data, dinamika psikologis perilaku agresif pada anggota ormas dapat dilihat dalam Gambar 1 di bawah ini:

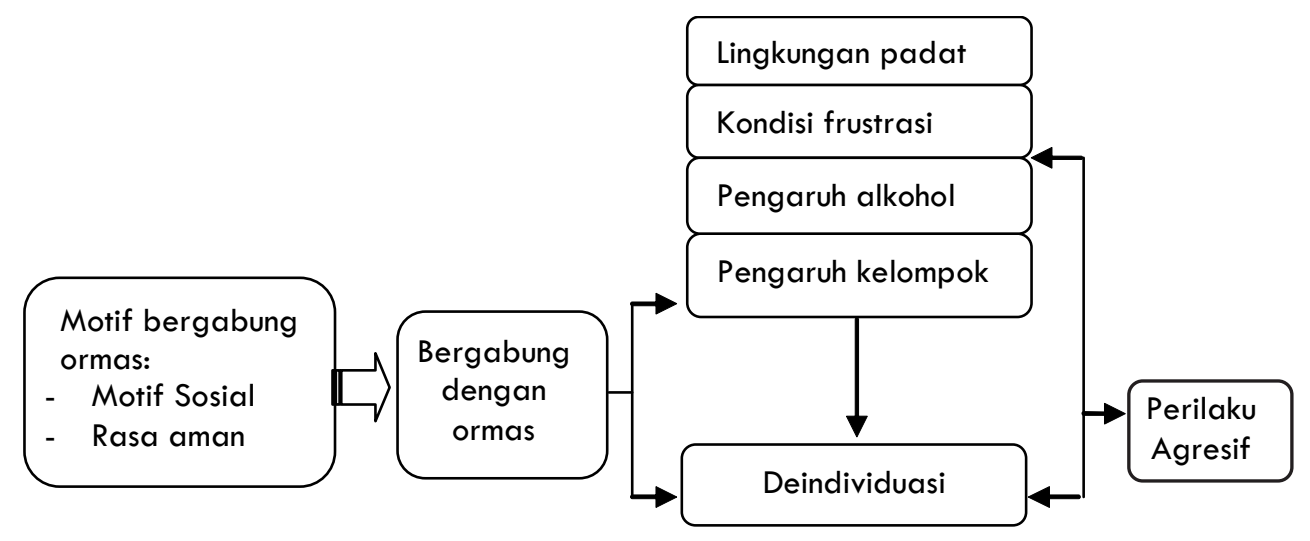

Gambar 1.

Dinamika Psikologis perilaku Agresif Anggota Ormas “ $X$ ”

Upaya untuk mereduksi tingkat perilaku agresif sebagaimana diusulkan oleh Siddiqah (2010) antara lain dengan menggunakan keterampilan mengelola marah (anger management). Hal tersebut berangkat dari asumsi bahwa sebelum perilaku agresi dimunculkan oleh individu, maka akan ada tarik menarik antara kutub kemarahan dengan kutub upaya pengendalian diri. Penguatan atas kutub upaya pengendalian diri akan mampu mengurangi kemungkinan munculnya perilaku agresi. Namun demikian, dalam konteks kelompok/ormas, penguatan atas kemarahan yang mendorong munculnya perilaku agresif jauh lebih kuat daripada upaya pengendalian diri yang dikembangkan individu. Upaya untuk mencegah munculnya perilaku agresif pada ormas ini, selain memerlukan penanganan yang sifatnya psikologis-individual, juga memerlukan penanganan yang sifatnya sistemik. Hal ini mengacu pada temuan penelitian yang menunjukkan bahwa faktor penyebab munculnya perilaku bukan hanya faktor mikro pada level individu, melainkan juga level yang lebih makro.

\section{Simpulan}

Beberapa faktor yang mempengaruhi perilaku agresi anggota ormas “ $\mathrm{X}$ ” ini meliputi pengaruh kelompok, deindividuasi, frustrasi, pengaruh alkohol dan obat-obatan, serta lingkungan fisik tempat tinggal. Perilaku agresif anggota ormas “ $X$ ” dilakukan secara spontan, seperti melakukan serangan balasan ketika salah satu anggotanya menjadi korban pengeroyokan, melakukan penindakan pada isu-isu tertentu yang terjadi dengan segera, dan melakukan penyerangan ketika ada kelompok lain yang mengancam 
keberadaan ormas “ $X$ ”. Perilaku agresif yang anggota ormas “ $X$ ” terhadap kelompok atau instansi lain juga meliputi perilaku agresif tidak tampak secara langsung.

\section{Daftar Pustaka}

Baron, R.A., \& Byrne, D. 2000. Social psychology (9th edition).Boston : Allyn and Bacon.

Bergsmann. E.M. De Schoot. R.V, Schober, B, Finsterwald, M. Spiel. Christiane. 2013. The effect of classroom structure on verbal and physical aggression among peers: A short-term longitudinal study. Journal of School Psychology 51, page: 159-174

Charters, M., Duffy, A.L., Nesdale,D. 2013. A social identity approach to explaining children's aggressive intentions. Journal of Applied Developmental Psychology 34 (2013) 163-172.

Demayo. C.G, Macabanding. J.B, dan Torres.M.A. 2011. Heritability of Aggressive Behavior in Selected Cultural Groups in Mindanao, Philippines. Australian Journal of Basic and Applied Sciences, 5(8): 438-445.

Farmer, T.W., Xie, H. 2007. Aggression and School Social Dynamics: The Good, The Bad, and The Ordinary. Journal of School Psychology 45 (2007) 461-478.

George \& Jones. 2002. Organizational Behavior. New Jersey: Prentice-Hall.

Karli, P. 2006. The Neurobiology of Aggressive Behavior. C.R. Biologies. 329. Page: 460-464.

Goldberg, C.B. 2003. Applicant Reactions To The Employment Interview: A Look At Demographic Similarity And Social Identity Theory. Journal of Business Research 56 (2003) 561-571.

Helm. P.V, Stams.G.J, Genabeek.M.V dan der Laan.P.V. 2012. Group Climate, Personality, and Self-Reported Aggression in Incarcerated Male Youth. The Journal of Forensic Psychiatry \& Psychology Vol. 23, No. 1, February 2012, 23-39.

Kemmelmeier. M, Broadus.A.D, dan Padilla.J.B. 2008. Inter-Group Aggression in New Orleans in The Immediate Aftermath of Hurricane Katrina. Analyses of Social Issues and Public Policy, Vol. 8, No. 1, 2008, pp. 211-245.

Koeswara, E. 1998. Agresi Manusia. Bandung : PT. Eresco. 
KOMPAS, Kapolri: Bekukan Ormas Bermasala, edisi 31 Agustus 2010.

Leonardelli, G.J., Pickett, C.L., and Brewer, M.B. 2010. Optimal Distinctiveness Theory: A Framework for Social Identity, Social Cognition, and Intergroup Relations. Advances in Experimental Social Psychology, Volume 43

MacLaren, V.V., Best, L.A., Bigney, E.E. 2010. Aggression-Hostility Predicts Direction Of Defensive Responses To Human Threat Scenarios. Personality and Individual Differences 49 (2010) 142-147

Myers. D.G, 1999. Social Psychology. New York: Irwin-McGrawHill.

Niens. U \& Cairns, E. 2007. Intrastate Violence.dalam Christie,D.J., Wagner,R.V., Winter,D.A. (Eds). (2001). Peace, Conflict, and Violence:Peace Psychology for The 21st Century. New Jersey: Prentice Hall.

Poerwandari, E, K. 1998. Buku Pendekatan Kualitatif Dalam Penelitian psikologi.Jakarta: LPSP3 Fakultas Psikologi Universitas Indonesia.

Salam, A. 2012. Negara dan Kekerasan Ormas. diakses dari http://www.setarainstitute.org/id/content/negara-dan-kekerasan-ormas.

Saout,V., Gambart,G., Leguay,D., Ferrapie.A.L., Launay,C., Richard.I. 2011. Agressive Behavior after Traumatic Brain Injury. Annals of Physical and Rehabilitation Medicine 54 (2011) 259-269.

Sarwono, S.W. 1999. Psikologi Sosial: Individu dan Teori Teori Psikologi Sosial. Jakarta: Balai Pustaka.

Siddiqah. L. 2010. Pencegahan dan penanganan perilaku Agresif Remaja melalui Pengelolaan Amarah (Anger management). Jurnal Psikologi Volume 37, No. 1, Juni 2010.

Stuart, G, W. And Sundeen, S, J. 1991. Principles and Practice of Psychiatric Nursing.St Louis: Mosby Compani.

Vanbrabanta, K., Kuppensa,P., Braekenb,J., Demaerschalka,E., Boerena,A., Tuerlinckx, F. 2012.ARelationship Between Verbal Aggression And Personal Network Size. Social Networks ed: 34. (2012), page: 164-170.

Vasquez. E.A, Lickel. B, Hennigan, K. 2010. Gangs, displaced, and group-based aggression. Aggression and Violent Behavior 15 (2010) 130-140.

Videbeck, S, L. 2008. Psychiatric-Mental Health Nursing (4th. ed). Philadelphia, PA: Wolters Kluwer. 